\title{
A Corpus Based Study on the Use of Preposition of Time 'on' and 'at' in Argumentative Essays of Form 4 and Form 5 Malaysian Students
}

\author{
Darina Lokeman Loke ${ }^{1}$, Juliana Ali $^{1} \&$ Norin Norain Zulkifli Anthony ${ }^{1}$ \\ ${ }^{1}$ Faculty of Educational Studies, Universiti Putra Malaysia, Serdang, Selangor, Malaysia \\ Correspondence: Darina Lokeman Loke, SMJK KwangHua, 41150 Klang, Selangor, Malaysia. Tel: 12-264-7474. \\ E-mail: scrubs_d@yahoo.com
}

Received: May 13, 2013 Accepted: June 17, 2013 Online Published: August 15, 2013

doi:10.5539/elt.v6n9p128 URL: http://dx.doi.org/10.5539/elt.v6n9p128

\begin{abstract}
This article presents a corpus- based investigation on English prepositions of time presented in the argumentative essays of Form 4 and Form 5 Malaysian secondary students in the MCSAW corpus. The aims were to find out the distribution patterns and the common errors in the use of preposition of time, 'on' and 'at'. This corpus based study investigated the distribution patterns of on and at in an argumentative type of essay. Furthermore, this study also highlighted some common errors found in the use of these preposition of time and prepare some possible explanations for the errors. Last but not least, the result of this study can provide suggestions on the teaching of preposition of time on and at and also the use of MCSAW Corpus for future studies.
\end{abstract}

Keywords: preposition, MCSAW corpus, argumentative essays, secondary students

\section{Introduction}

Preposition usage is one of the most difficult aspects of English grammarfor non-native speakers to master. 'It is difficult to learn to use prepositions correctly in a foreign language' (Swan, 1988).Prepositions have been called the biggest little words in English. There usually quite short and insignificant looking but they have very important functions (Mus, 2012).

A preposition is a word that shows the relationship between two words in a sentence. These relationships include those of time, position, direction, and various degrees of mental and emotional states (Castro, M. C. S. A, 2013).

Why are prepositions so difficult to master? An obvious reason is that the number of prepositions used in English is limited but they have to serve a variety of relational meanings (Quirk, Greenbaum, Leech \&Svartvik, 1985).Most of the ESL or EFL learners usually try to relate the use of English prepositions to their mother tongue (MT) prepositional system (Jha, A. K, 1991; Hasan, A. A. \& Abdullah, I.H, 2009; Castro, 2013) that is why learners are having problems in using prepositions in their writing.

In the context of Malaysian education system, the syllabus of the KurikulumBersepaduSekolahMenengah (KBSM) enunciate that the teaching of grammar needs to be integrated into the four language skills and to be taught in context and in a meaningful way. Grammar should not be taught in isolation or as an independent item. Teachers are required to teach grammar as listed in the syllabus (Mukundan, J. \&Roslim. N, 2009).

The standard of English among Malaysian learners is on the decline despite learning English for 11 years. Malaysian students are still weak in English, especially in their writing skills. They still seem to commit errors in all aspects of language (Darus\&Subramaniam, 2009). This study therefore specifies its focus on examining the distribution patterns and errors made in using preposition of time in the Malaysian Corpus on Student's Argumentative Writings (MCSAW).

\section{Objective of the Study}

The objective of this study is to investigate English prepositions of time, 'on' and 'at'presented in the Malaysian Corpus on Student's Argumentative Writings (MCSAW) from Form 4 and Form 5 in Malaysia.

Research Questions

In view of the objective mentioned above, this study attempts to answer the following research questions:

1) Whatare the distribution patterns of prepositions of time, 'on' and ' $a t$ ' in the Malaysian Corpus on Student's 
Argumentative Writings (MCSAW) of Form 4 and Form 5 students?

2) What are the common errors in the use of preposition of time, 'on' and 'at' made by the Form 4 and Form 5 students in theMalaysian Corpus on Student's Argumentative Writings (MCSAW)?

\section{Literature Review}

\subsection{English Language Learner Corpus}

A learner corpus is a collection of authentic texts produced by foreign or second language learners, stored in electronic format. The texts can be either spoken or (primarily) written material. Although any collection of student written material gathered together by teachers can be considered a learner corpus, such a collection is not considered a corpus proper unless it is planned and collected according to clear and sound design principles (Botley \& Dillah, 2007).

A learner corpus, however it is designed, can be used for many purposes, but a common application is in the investigation of the features of language used by students who are learning a new language(Selinker, 1972).This means that a learner corpus offersmany researchers and language teachers around the world information on learners' interlanguage development and gain insights about leaner's difficulties and needs during the language learning process.

Some examples of English language corpora in Malaysia are:

1) EMAS (English of Malaysian School Students) corpus (Arshad et al, 2002)

2) MACLE (Malaysian Corpus of Learner English) (Knowles and Zuraida, 2004)

3) CALES (Corpus Archive of Learner English in Sabah-Sarawak) (Botley et al, 2005, 2007).

4) Pedagogic corpus of Malaysian English language textbooks (Mukundan and Anelka, 2007)

5) Malaysian secondary school EST and Science textbook corpus (Menon and Mukundan, 2012)

\subsection{Studies Conducted on Learner's Difficulties Inprepositions}

Learners of Malaysian school have problems in using prepositions. Mohamed, Abdul Rashid, Li LianGoh, and Wan Rose Eliza, (2004) conducted a study consisted of 305 Form Four students studying in a national type Chinese secondary school in Penang in northern Malaysia. The occurrence of multiple errors in a single sentence was found very common among the respondents and one of the errors is on the use of prepositions.

Darus and Subramaniam, (2009) examined errors in a corpus of 72 essays written by 72Form Four Malay students. The findingsshowed that six most common errorscommitted by the participants were singular/plural form, verb tense, word choice,preposition, subject-verb agreement and word order.

Another study by Darus, S., \& Ching, K. H. (2009) in investigating the most common errors in essays written in English by 70 Form One Chinese students in a selected public school in Perak showed that prepositional errors account for $9.0 \%$ of the total number of errors in the corpus study.

A study conducted by Yahya, Ishak, Zainal, Faghat, and Yahaya (2012) on 30 studentsnarrative and descriptive essays from secondary school aged fourteen detected eleven types of errors committed by the students. One of the errors which the students experienced in their writing includes the use of prepositions.

There are also studiesdone on the use of prepositions in a corpus based research. Mukundan, J., \& Roslim, N. (2009) investigate the use of English prepositions which are presented in three English language textbooks used by lower secondary schools in Malaysia. It is found that there was a difference between the textbook corpus and the British National Corpus (BNC) in terms of the order of these grammatical items. Another finding was the similarities and differences of the use of these items as prepositions in textbooks in terms of their co-occurrence with other parts of speech.

In another study by Roslim, N., \& Mukundan, J. (2011) stated thatmore studies need to be conducted to add to the body of knowledge as prepositions are constant source of difficulty for the ESL/EFL learners and therefore must be taken seriously and studied more systematically.

Preposition is not only a common error in the Malaysian school but it is also posing a problem to others. A study by Hasan, A. A., \& Abdullah, I. H, (2009) said that among Arab EFL learners, prepositions are considered to be the most difficult because of cross-linguistics differences between the Arabic and English prepositional system.

Jha, A. K. (1991) conducted a study on Maithili, Nepal learners of English and found that the error in the use of prepositions by Maithili learners of English is really a matter of great concern for the teachers and resulting in their university entrants having formed bad language habits. 
Ahmad,Nasir, Bukhari.,M.A. \&Hussain, Shafqat(2011) in his study on 100 randomly selected students from government secondary schools of Khyber Pukhtunkhwa, Pakistan found that secondary school students faced more difficulties in learning prepositions as compare to articles and that they were confused while using preposition in their writings.

Catalán, R. M. J. (1996) in her study indicate that English prepositions are difficult for third year Spanish secondary students. With the high frequency of preposition errors detected in the study gives her sound reasons to believe that English prepositions must be considered as a difficult area forSpanish learners of English.

\subsection{Prepositions in F4 and F5 KBSM Syllabuses}

In the Form 4 and Form 5 KBSM syllabuses, English prepositions that are listed to be taught in the upper secondary schools include preposition of place (in, on, near, under, behind, in front of, by),prepositions of time (at, on, by, before, after, since, during, until, within),prepositions of direction( out of, away from),prepositions of purpose (for, so that, in order to) ,prepositions of association (among, between) ,verb and preposition combination and adjective and preposition combination (phrasal verbs).

In this study, the importance of English preposition of time can also be observed in terms of their frequent occurrences in students writing. We have identified that the prepositions on and at were the top 2 most frequents preposition used in the students argumentative essays as appeared in the MCSAW corpus. So, the high occurrences of these two words suggest the importance of these prepositions in writing. These grammatical features are important to be emphasize as it is a part of the grammatical items in the Form 4 and Form 5 KBSM syllabuses.

\subsection{Error Analysis}

Students of second language learning have been making mistakes in both their speaking and written form. Mistakes are inevitable especially in the process of learning a new language. Corder who is the forerunner of error analysis (EA) said: (cited from Mohamed Ali, H. M, 1996).

"The study of error is part of the investigation of the process of language learning. In this respect it resembles methodologically the study of the acquisition of the mother tongue. It provides us with a picture of the linguistic development of a learner and may give us indications as to the learning process."

There are three types of errors in relation to the use of preposition as in the study of Jha, A. K, 1991; Bram.Barli, 2005; Chodorow, M., Tetreault, J. R., \& Han, N. R, 2007.

1) Omission of Preposition - learners fail to use a preposition in a sentence where it is obligatory.

2) Insertion of Preposition - learners add on preposition in a sentence where it is not needed.

3) Selections of Incorrect Preposition- learners use the wrong preposition in a sentence.

\section{Methodology}

This corpus-based study looks at a corpus of upper secondary school and college students in Malaysia argumentative essays and utilizes a concordance software WordSmith Tools version 4.0.

\subsection{The MCSAW Corpus}

The first version of the Malaysian Corpus on Student's Argumentative Writings (MCSAW) (Mukundan, J. RezavaniKalajahi, and S.A, 2013)was collected through English language teachers who were attending a Professional Development Course in Master level at UPM. A general objective of the corpus construction was to collect samples of student written data for the purpose of establishing baseline data of the English language proficiency of Malaysian students in writing. Another objective was to establish benchmarks of student English language proficiency. Finally, the research also intended to examine developmental patterns through data obtained from three age levels - Form 4, Form 5 and College students.

The respondents for this study were 1010 students from Form 4, Form 5, and college student schools in Malaysia. MCSAW consists of 605,300 running words. Only written data in the form of an essay were collected from the students. The essay was entitled "Do you think Facebook have more advantages than disadvantages?

\subsection{Concordance Software}

WordSmith Tools 4.0 is an integrated suite of programs for looking at how words behave in texts. We will able to use tools to find out how words are used in our own texts or those of others. The Wordlist tool lets us see a list of all the words or word-clusters in text, set out in alphabetical or frequency order. The concordance, concord gives us a chance to see any words or phrase in context, so that we can see what sort of company it keeps. With 
KeyWords we can find the keywords in a text. The tools are used by Oxford University Press for their own lexicographic work in preparing dictionaries, by language teachers and students, and by researchers investigating language patterns in lots of different languages in many countries world-wide.

\section{Results and Discussion}

The analysis and discussion of this study will follow the order of research questions stated earlier.

1) What are the distribution patterns of prepositions of time, 'on' and 'at' in the Malaysian Corpus on Student's Argumentative Writings (MCSAW) from Form 4 and Form 5 students? (RQ1)

In determining the correct use of preposition of time on and at several parameters were set as guidelines for the analysis. These parameters were set according to Quirk, R., Greenbaum, S., Leech, G., and Svartvik, J. (1985).

Table 1. Parameters of the correct use of the preposition atand on as preposition of time

\begin{tabular}{ll}
\hline Parameter & Description \\
\hline 1 & At is used for points of time \\
& Example : at 10 o'clock \\
& At is used for holiday periods \\
& Example: at the weekends \\
3 & On is used for referring to days as periods of time \\
& Example: on Monday \\
& On is used for expression \\
& Example: on the hour
\end{tabular}

The concordance output was edited and the all the occurrences that did not show the use of preposition of time at and on according to the parameters were removed.

Preposition on appeared 19/904 times for Form 4 and the frequency increased in the Form 5 with 21/ 856 times.

Meanwhile for preposition at according to the parameters has appeared 9/240 times for Form 4 and the frequency increased in the Form 5 with 11/ 250 times.

\subsection{Discussion}

The distribution pattern of on and atas preposition of time is limited in this corpus despite having high frequency occurrences. This is because the word on and at are not used as preposition of time in the corpus.

Another reason is due to the type of essayused in this corpus which is an argumentative essay. In this type of essay it refrains students from using preposition of time.

2) What are the common errors in the use of preposition of time, 'on' and 'at' made by the Form 4 and Form 5 students in the Malaysian Corpus on Student's Argumentative Writings (MCSAW)?(RQ2)

In determining the common errorsin the use of preposition of time at and on several parameters were set as guidelines for the analysis. These parameters were set according to the study of Jha, A.K, 1991; Bram.Barli, 2005; Chodorow, M.Tetreault, J. R. \& Han, N. R. 2007.

Table 2. Parameters of common errors in the use of preposition of time

\begin{tabular}{ll}
\hline Parameter & Description \\
\hline \multirow{3}{*}{1} & Omission of Preposition - learners fail to use a preposition in a sentence where it is \\
& obligatory \\
& Example: a) My class started 10 to 4 o'clock. \\
& Insertion of Preposition - learners add on preposition in a sentence where it is not \\
& needed \\
& Example: I read the books since to 4 o'clock. \\
& Selections of Incorrect Preposition- learners use the wrong preposition in a sentence \\
& Example: I came in Campus at 10 o'clock. \\
\hline
\end{tabular}


Table 3. The categories of errors in the use of the preposition of time, at

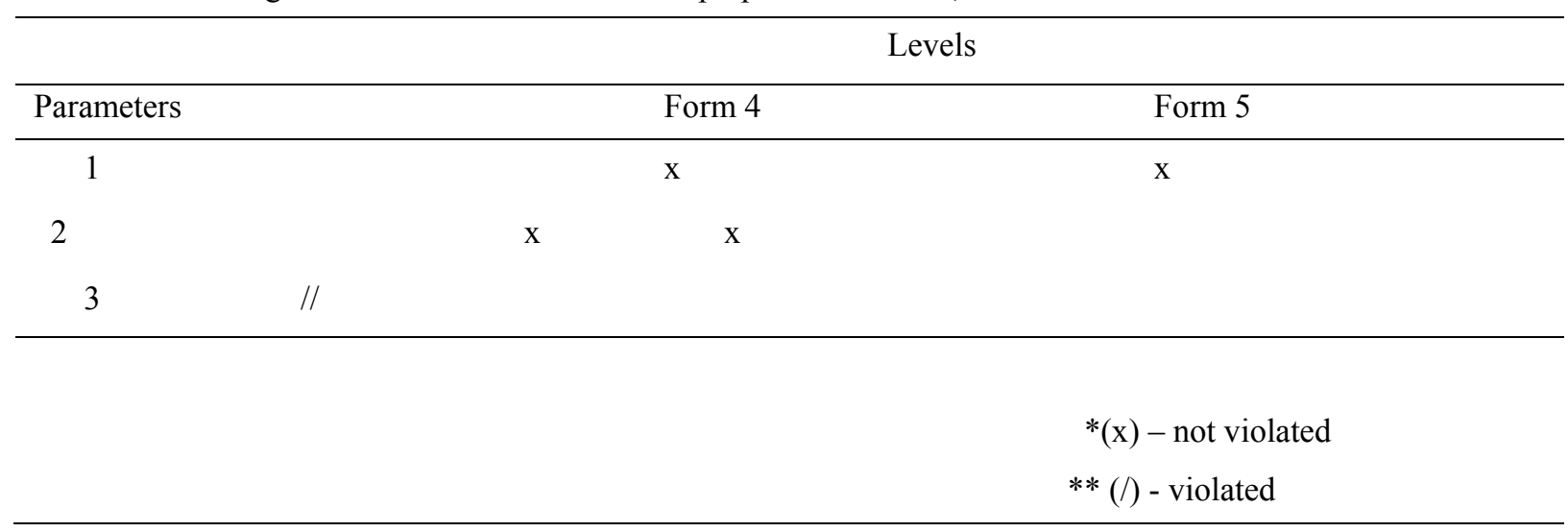

N/B: Of the 3 parameters that were used to categorize errors, only 1 were violated. The form 4 students violated parameter 3 (with 7 errors: $77.8 \%$ ). The form 5 students violated parameter 3 (with 5 errors: $45.5 \%$ )

Parameter 3

In the use of the preposition at, the form 4 and form 5 students shared the same category of errors in which the preposition at was used wrongly in a sentence.

Example:

a) Facebook was created at 2008 by a younger man

Table 4. The categories of errors in the use of preposition of time, on

\begin{tabular}{|c|c|c|c|}
\hline \multicolumn{4}{|c|}{ Levels } \\
\hline Parameters & & Form 4 & Form 5 \\
\hline 1 & $\mathrm{x}$ & $\mathrm{x}$ & \\
\hline 2 & \multicolumn{2}{|r|}{$\mathrm{x}$} & / \\
\hline 3 & l & / & \\
\hline \multicolumn{4}{|r|}{$*(\mathrm{x})-$ not violated } \\
\hline & & & $* *(/)$ - violated \\
\hline
\end{tabular}

N/B: Of the 3 parameters that were used to categorize errors, 2 were violated. The form 4 students violated parameter 3 (with 3 errors: 15\%). The form 5 violated parameter 2(with 1 error: 4.7\%) and parameter 3 (with 3 errors: $14.2 \%)$.

\section{Parameter 2}

In the use of the preposition on, the form 5 student add on preposition in a sentence where it is not needed.

Example:

b) All things have their own ups and downs, thus we have to choose wisely so that we will not regret on the next day

\section{Parameter 3}

The form 4 and form 5 students shared the same category of errors in the use of preposition, on. Based on the parameter the preposition on was wrongly used in a sentence.

\section{Example:}

c) Moreover, we can do some business on Facebook on the free time or as a career. 


\subsection{Explanation of Errors}

In explaining the errors, only some possible explanations of errors based on this analysis will be considered as this study does not set out to investigate the source of the students' errors thoroughly because of the enormity of the task.

In the analysis, one possible explanation of errors is due to the students' difficulties in understanding the use of preposition of time. Thus, the students had used the wrong preposition as they were unsure with the usage of preposition of time as shown below:

a) On the same time, if we saw any accident...

b) At 21 century, many people also had a Facebook account...

c) We will also less exercise at evening....

\section{Conclusion}

In utilizing a learner corpus, this study had shown that there were difficulties faced by students in handling preposition of time on and atin their writing. If teachers are perceptive to this, then they could implementappropriate teaching strategies to reinforce the students' use of preposition of time. If this is done systematically, the learning of English will become meaningful.

From the results of the study, if effort were put in by teachers and students, the learning of English grammar would be both rewarding and motivating for all parties concerned.

The findings have shown several insights in this study. Firstly, due to the type of essay used in this corpus which is an argumentative essay the distribution patterns of on and at are limited in this corpus. In an argumentative essays it refrain students from using preposition of time however where the prepositions are used errors were committed by students.

Lastly, this study has revealed that students' are having difficulties in understanding the correct use of preposition of time. For example students commit errors where they add on preposition in a sentence where it is not needed and also use wrong preposition.

\section{Recommendations}

The outcomes of this corpus-based study could be used as guidelines to provide recommendations on the teaching of English as Biber, Conrad and Reppen (1994) suggested, "corpus-based research sheds new light on some of our most basic assumptions about English grammar, and as a result it offers the possibility of more effective and appropriate pedagogical applications."

Teachers' intervention is needed in emphasizing the correct usage of preposition. Teachers should come up with extra materials that could help students learn more on the use of preposition of time. These activities will help students to have a better understanding of the usage and functions of preposition.

As it has been emphasized the teaching of grammar is to be incorporated into the four language skills and should be taught in context and in a meaningful way. Hence, it may be then that we shouldn't teach certain prepositions in isolation but rather to teach them as in relation to their occurrence with other words (Celce-Murcia \& Larsen-Freeman, 1999)

Another interesting way in introducing and teaching grammar, teachers may consider using a concordance. A concordance is a computer program which is used to find the occurrences of every single word or phrase in a text (Sinclair, 1991). Teachers could also retrieve concordance entries from the accessible website and prepare exercises for their students. The concordance and concordancing is one example where it can promote independent learning. Such an approach may help to boost students' self-confidence. Students may be able to learn and recognize the pattern and the uses of prepositions better if they are learning it on their own. The students' awareness toward the language can also be developed if they are encouraged to discover the pattern of use in learning prepositions.

Finally, further research is required in this area. Other researchers could look into other preposition of time such as since, during and within. Besides that, they can also study the usage of at and on in different types of essays such as narrative, report, letter writing and so on as it has not been researched yet.

\section{References}

Abas, Suriati. (2012). A Study on the Use of Prepositions mediated by an ICT Tool: ICCE 2012. The 20th International Conference on Computers in Education. Retrived from: http://www.lsl.nie.edu.sg 
Ahmad, Nasiret, et al. (2011). Error Analysis: Learning Articles and Prepositions among Secondary School Students in Pakistan. Interdisciplinary Journal of Contemporary Research In Business. Institute of Interdisciplinary Business Research.

Arshad, et al. (2002). The English of Malaysian School Students (EMAS) corpus. Serdang: Universiti Putra Malaysia Press.

Biber, D., Conrad, S., \& Reppen, S. (1994). Corpus-based approaches to issues in Applied Linguistics. Applied Linguistics, 15(2), 167-187.

Botley, S. P., De Alwis, C., Metom, L., \& Izza, I. (2005). CALES: A Corpus-Based Archive Of Learner English In Sarawak. Final Project Report, Unit for Research, Development and Commercialisation, UniversitiTeknologi MARA.

Botley, S., \& Dillah, D. (2007). Investigating spelling errors in a Malaysian learner corpus. Malaysian Journal of ELT Research, 3, 74-93.

Bram, Barli. (2005). Some Common Problems Involving Prepositions in Writing English in a Multilingual Context. Retrived from http://www.academia.edu

Castro, M. C. S. A. (2013). An Analysis of Prepositional Errors of College Students. Retrieved from http://www.fllt2013.org

Catalán, R. M. J. (1996). Frequency and variability in errors in the use of English prepositions.Miscelánea: $A$ Journal of English and American Studies, 17, 171-187.

Celce-Murcia, M., \& Larsen-Freeman, D. (1999). The Grammar Book: An ESL/EFL Teacher's Course (2nd Ed.). USA: Heinle \& Heinle Publishers.

Chodorow, M., Tetreault, J. R., \& Han, N. R. (2007). Detection of grammatical errors involving prepositions. In Proceedings of the Fourth ACL-SIGSEM Workshop on Prepositions (pp. 25-30). Association for Computational Linguistics.

Darus, S., \& Ching, K. H. (2009). Common errors in written English essays of form one Chinese students: A case study. European Journal of social sciences, 10(2), 242-253.

Darus, S., \& Subramaniam, K. (2009). Error analysis of the written English essays of secondary school students in Malaysia: A case study. European Journal of Social Sciences, 8(3), 483-495.

Hasan, A. A., \& Abdullah, I. H. (2009). A Comparative Study of English and Arabic Use of Prepositions Amongst Arab Native Speakers.

Jha, A. K. (1991). Errors in the Use of Prepositions by Maithili Learners of English and Their Remedies. Tribhuvan University Journal, 14, 49-57.

Kementerian, Pendidikan, Malaysia. (1995). Huraian Sukatan Pelajaran Bahasa Inggeris Tingkatan 4. Pusat Perkembangan Kurikulum.

Kementerian, Pendidikan, Malaysia. (1995). Huraian Sukatan Pelajaran Bahasa Inggeris Tingkatan 5. Pusat Perkembangan Kurikulum.

Knowles, G., \& Zuraidah, Mohd, Don. (2004). Introducing MACLE: The Malaysian Corpus Of Learner English. 1st National Symposium of Corpus Linguistics and Foreign Language Education, South China Normal University, Guangzhou, China.

Menon, S., \& Mukundan, J. (2012). Collocations of High Frequency Noun Keywords in Prescribed Science textbooks. International Education Studies, 5(6), 149-160.

Mohamed, Ali, H. M. (1996). Error analysis-contributory factors to students' errors, with special reference to errors in written English. The English Teacher, 25.

Mohamed, A. R., Goh, L. L., \& Eliza, W. R. (2004). English errors and Chinese learners. Sunway Academic Journal, 1, 83-97.

Mukundan, J., \& Anealka, A. H. (2007). A forensic study of vocabulary load and distribution in five Malaysian Secondary School Textbooks (Forms 1-5). Pertanika Journal of Social Science and Humanities.

Mukundan, J., \& Roslim, N. (2009). Textbook representation of prepositions.English language teaching, 2(4), 13.

Mukundan, J., \& Rezavani Kalajahi, S. A. (2013). Malaysian Corpus of Students' Argumentative Writing 
(MCSAW).Australia, Australian International Academic Center.

Mus, Musliyanti. (2012). THE STUDENTS'ABILITY IN USING PREPOSITION “A Case Study at Faculty of Letters of Hasanuddin University" (Doctoral dissertation). Retrieved from http://repository.unhas.ac.id/

Norwati, R. (2004). A Corpus-based Study on an English Preposition of Place 'AT'. ELT Matters 2: Developments in English Language Learning and Teaching.

Quirk, R., Greenbaum, S., Leech, G., \& Svartvik, J. (1985). A Comprehensive Grammar of the English Language. Longman.

Roslim, N., \& Mukundan, J. (2011). An overview of corpus linguistics studies on prepositions. English Language Teaching, 4(2), 125.

Selinker, L. (1972). Interlanguage. International Review Of Applied Linguistics, 10(3), 209-311.

Sinclair, J. (1991). Corpus, concordance, collocation: Describing English language. Oxford: Oxford University Press.

Shamsudin, S., \& Mahady, N. R. A. (2010). Corpus linguistics based error analysis of first year Universiti Teknologi Malaysia students' writing. Corpus Linguistics Based Error Analysis of First Year Universiti Teknologi Malaysia Students’ Writing, 1-7.

Swan, M. (1988). Practical English Usage. Oxford: Oxford University Press.

Vethamani, M. E., Umi Kalthom Abd Manaf, \& OmidAkbari. (2008). ESL Learners' Use of English Modals in Narrative Compositions: Syntactic and Semantic Accuracy. TEFLIN Journal, 19(2).

Yahya, A., Ishak, H. B., Zainal, Z., Faghat, L. J., \& Yahaya, N. (2102). Error Analysis of L2 Learners' Writings, a Case Study. International Conference on Language, Medias and Culture IPEDR, 33. Retrieved from http://www.ipedr.com

Yusuf, Y. Q. (2009). A Corpus-Based Linguistics Analysis on Written Corpus: Colligation of "TO" and "FOR". Journal of Language and Linguistic Studies, 5(2), 104-122.

\section{Copyrights}

Copyright for this article is retained by the author(s), with first publication rights granted to the journal.

This is an open-access article distributed under the terms and conditions of the Creative Commons Attribution license (http://creativecommons.org/licenses/by/3.0/). 